\title{
Sweet disaster: use of honey- based eye drops as an alternative treatment for vernal keratoconjunctivitis
}

Kenneth Teow Kheng Leong ${ }^{1,3}$, Rebecca Jennifer Mary Louis ${ }^{1}$, Lai Yin Peng ${ }^{2}$, Rohanah Alias $^{1}$, Safinaz Mohd Khialdin ${ }^{3}$

${ }^{1}$ Department of Ophthalmology, Hospital Kuala Lumpur, Kuala Lumpur, Malaysia; ${ }^{2}$ Department of Ophthalmology, Hospital Sungai Buloh, Jalan Hospital, Selangor, Malaysia; ${ }^{3}$ Department of Ophthalmology, Hospital Universiti Kebangsaan Malaysia, Kuala Lumpur, Malaysia

\section{Abstract}

A 16-year-old boy with underlying bronchial asthma, vernal keratoconjunctivitis, and bilateral eye steroid-induced glaucoma presented with right eye itchiness, redness, and progressive painful blurring of vision for the past 3 weeks. His mother had been treating him with honey-based eye drops purchased from an unregistered source/ traditional healer. On presentation his right visual acuity was counting fingers, the cornea was hazy, and a small central stromal abscess with a large endothelial plaque was seen in the anterior chamber. He was treated for right eye fungal keratitis and subsequently admitted for intensive treatment. He showed marked improvement and was discharged. His final vision on follow-up was 6/15.

Keywords: Vernal keratoconjunctivitis, corneal ulcer, fungal, honey

Correspondence: Dr. Kenneth Teow Kheng Leong, Department of Ophthalmology, Hospital Kuala Lumpur, Kuala Lumpur, Malaysia.

Email: kennethteow@yahoo.com 


\section{Bencana akibat manis: penggunaan ubat mata berasaskan madu sebagai rawatan alternatif untuk keratokonjunktivitis vernal}

\section{Abstrak}

Seorang budak lelaki berusia 16 tahun yang mempunyai latarbelakang penyakit asma bronkus, keratoconjunktivitis vernal, dan glaukoma yang disebabkan oleh steroid dirujuk dengan masalah gatal mata, kemerahan, dan kabur penglihatan serta sakit yang semakin teruk selama 3 minggu. Ibu beliau telah merawatnya dengan ubat titisan mata berasaskan madu yang dibeli dari sumber yang tidak berdaftar/pengamal perubatan tradisional. Ketajaman penglihatan pada kali pertama di hospital ialah menghitung jari, dan kornea kabur, dan nanah pada pusat stromal yang kecil dengan plak endothelial besar dilihat di ruang anterior. Dia dirawat untuk keratitis kulat mata kanan dan seterusnya dimasukkan ke wad untuk rawatan intensif. Beliau menunjukkan peningkatan yang ketara dan dibenarkan pulang. Ketajaman penglihatan terakhirnya pada tarikh susulan ialah $6 / 15$.

Kata kunci: Keratoconjunctivitis Vernal, ulser kornea, kulat, madu

\section{Introduction}

Vernal keratoconjunctivitis (VKC) is a seasonally occurring allergic eye disease that typically affects young males. The common signs and symptoms are itching, photophobia, burning, tearing, giant papillae, superficial keratitis, and conjunctival hyperaemia. These patients frequently have a family or medical history of atopic diseases, such as asthma, rhinitis, and eczema. ${ }^{1}$ Due to the chronicity of the disease and multiple relapses, some patients seek alternative treatment such as herbal and traditional medications to remedy their condition.

\section{Objective}

To report a case of fungal keratitis with underlying VKC. 


\section{Case description}

A 16-year-old boy with underlying bronchial asthma, VKC, and bilateral eye steroid-induced glaucoma presented with right eye itchiness, redness, and progressive painful blurring of vision for the past 3 weeks. Further history revealed that his mother had been treating him with honey-based eye drops purchased from an unregistered source/traditional healer for the past month.

On examination, the right visual acuity was counting fingers. Anterior segment examination showed a hazy cornea, a small central stromal infiltrate, and a large endothelial plaque measuring $4 \mathrm{~mm}(\mathrm{H}) \times 2 \mathrm{~mm}$ (W) (Fig. 1). The anterior chamber activity was undetermined; however, it was deep and there was no satellite lesion or hypopyon seen. Corneal scraping was performed but the result was negative.

He was clinically diagnosed with right eye fungal keratitis and admitted for intensive eye drops. Guttae Fluconazole $0.02 \%$, Guttae Natamycin 5\%, Guttae Moxifloxacin $0.5 \%$, and Guttae Gentamycin $0.9 \%$ were started hourly for the right eye. He was also treated with oral Fluconazole $200 \mathrm{mg}$ daily and responded well after a week of treatment. The endothelial plaque had resolved and the stromal infiltrate was smaller. He was discharged with topical eye drops and reviewed a week later in clinic (Fig. 2). Topical eye drops were tapered down during each subsequent outpatient visit and his best vision had improved to $6 / 15$.

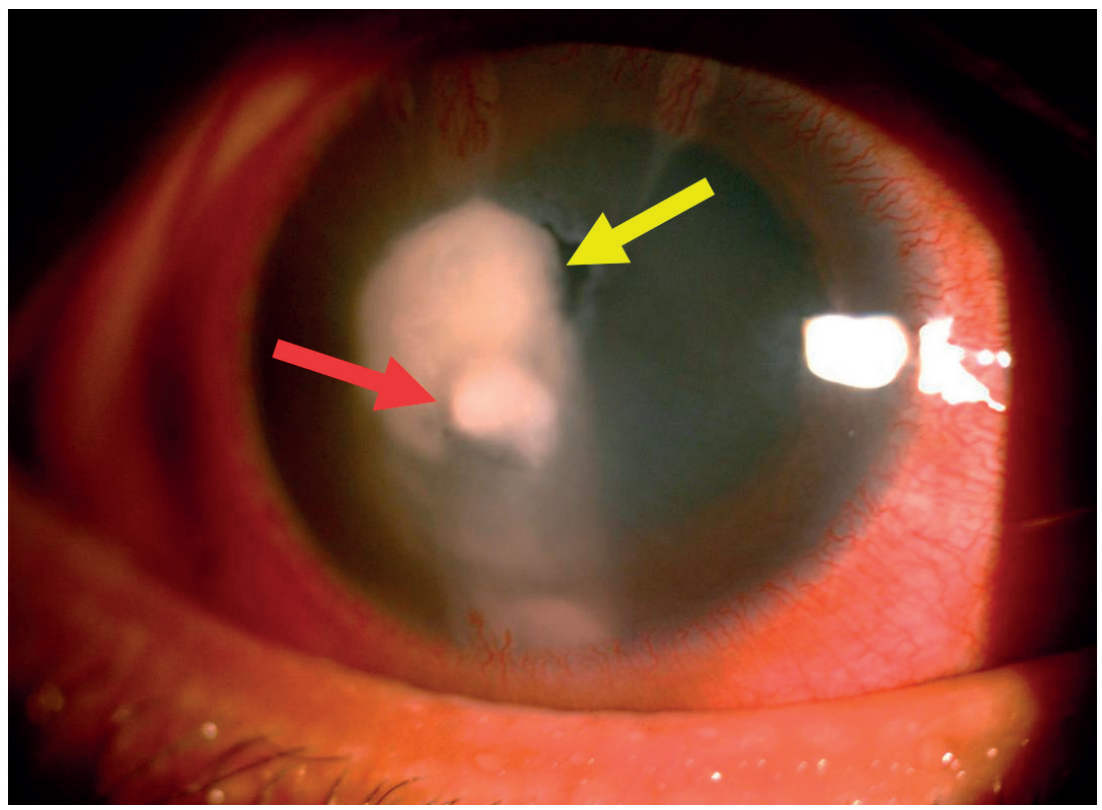

Fig. 1. Shows a fungal-like corneal ulcer with a small central stromal abscess (red arrow) and a large endothelial plaque in the anterior chamber (yellow arrow). 


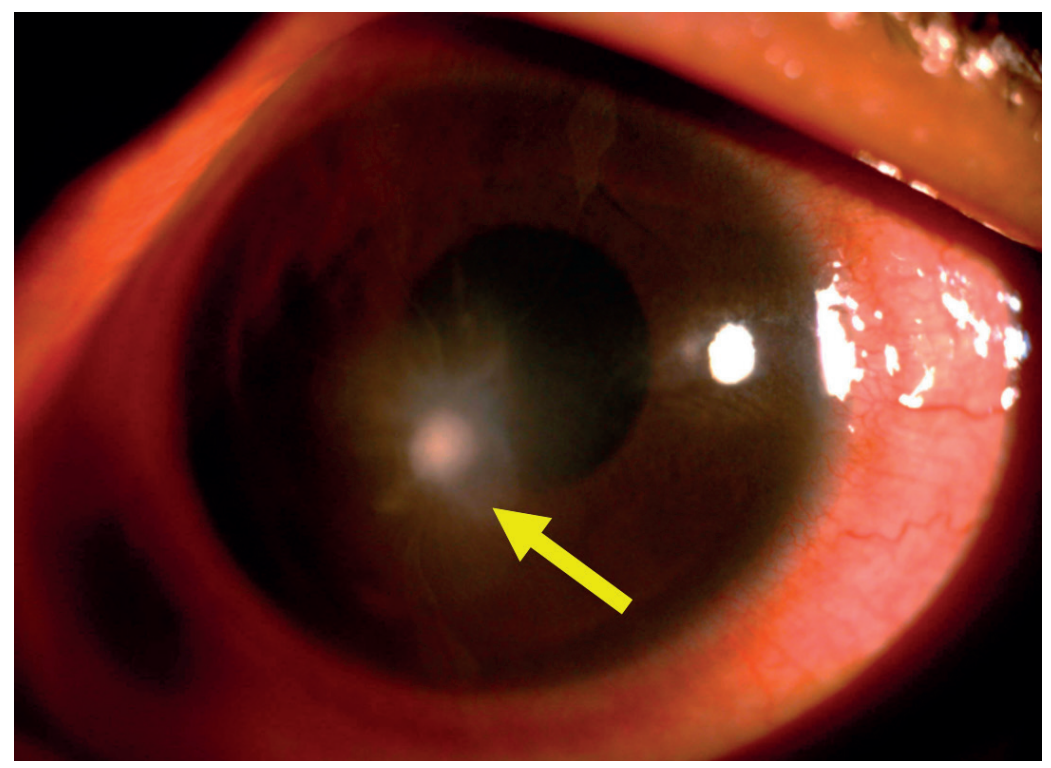

Fig. 2. Shows a healing corneal ulcer with mild scarring (yellow arrow).

\section{Discussion}

In VKC the therapeutic options are mainly topical eye drops, and they are selected based on the severity of the disease. ${ }^{2} \mathrm{~A}$ vicious cycle of inflammation occurs as a result of reciprocal interactions between the conjunctiva and cornea, which results in damage to the corneal epithelium and stoma, leading to the formation of shield ulcers and plaques, infectious keratitis, keratoconus, scarring, and limbal stem cell deficiency. ${ }^{3}$

The aim of VKC treatment is to remove all possible allergens and suppress allergic inflammatory responses in the eye with the use of topical antihistamine and mast cell stabilizers. Corticosteroids are most effective; however, a quick tapering and use of low-absorption corticosteroids is preferred to avoid secondary development of glaucoma. Alternatively, immunomodulators such as cyclosporine may be considered as a steroid sparring option. ${ }^{1}$ The long-term prognosis for patients is generally good; however, $6 \%$ of patients develop corneal damage, cataract, or glaucoma. ${ }^{2}$

This article explores the use of honey in traditional eye treatment. Is it a practice that should be discouraged or are there medicinal values and scientific benefits? Recent studies explored the use of honey as a complimentary treatment for corneal wounds and even VKC. A double-blinded study on patients with VKC showed a significant reduction in redness and limbal papillae following the application of the 
honey drops when compared to placebo control group. ${ }^{4}$ Widely researched are the Manuka and Tualang honeys among others, and they have been found to possess high antimicrobial and wound healing abilities. ${ }^{5,6}$

The antimicrobial activity is attributed to the presence of hydrogen peroxide producing enzymes, acidic $\mathrm{pH}$ of 3.2 - 4.5, high osmolarity, and phytochemicals, such as flavonoids and polyphenols, which may function as antioxidants. ${ }^{5,7}$ Apart from this, honey maintains a moist wound environment, and its high viscosity helps form a protective barrier to prevent infection. ${ }^{5}$ It also exhibits anti-biofilm, anti-inflammatory, and immunomodulatory properties. ${ }^{5,8}$

Corneal fibroblasts migrate and synthesize new extracellular matrix, while myofibroblasts are essential for wound contraction during healing. A study showed that growing corneal fibroblasts in honey-enriched media promotes faster migration and wound closure compared to controls. ${ }^{6}$ Hydrogen peroxide provides adequate oxygen and nutrients to the injured tissue through angiogenesis. ${ }^{6}$ Honey has been reported to lessen wound $\mathrm{pH}$, reduce protease activity, increase fibroblast activity, and elevate oxygen release, which in turn facilitates wound healing. ${ }^{6}$ Honey was also shown to reduce the expression of alpha smooth muscle actin ( $\alpha$-SMA) and increase the expression of lumican. This indicates potential reduction of corneal scarring and increased corneal transparency. ${ }^{6}$

Despite the benefits of honey, many studies have found a range of contaminants in honey, such as pesticides, heavy metals, microorganisms (bacteria and fungus), and many more. ${ }^{7,9}$ Therefore, the application of honey as a topical eye drop should be thoroughly sterilized and processed to remove unwanted and harmful contaminants.

This patient most likely developed a shield ulcer due to poorly controlled VKC, subsequently complicated by a fungal infection derived from the homemade honey eye drops. The diagnosis of a fungal corneal ulcer was made on the basis of the characteristic appearance of the fungal infection. Corneal scraping is an important diagnostic tool; however, it may not always be positive and culture and sensitivity testing may take up to three weeks to yield any confirmation. ${ }^{10}$ Therefore, good clinical judgment and prompt treatment are essential for a good visual outcome.

\section{Conclusion}

Honey-based eye drops have shown positive and promising results as an alternative or complementary treatment for corneal wounds, ulcers, and even VKC in the future. However, patients should be cautious when instilling unsterilized, honey-based eye drops from unapproved sources, otherwise it may do more harm than good. 


\section{References}

1. Kraus CL. Vernal keratoconjunctivitis. External/Anterior Segment. [American Academy of Ophthalmology]. April 28, 2016. Available at: https://www.aao.org/disease-review/vernal-keratoconjunctivitis-5. Accessed May 8, 2019.

2. Bonini S, Coassin M, Aronni S, Lambiase A. Vernal keratoconjunctivitis. Eye (Lond). 2004;18(4):34551.

3. Solomon A. Corneal complications of vernal keratoconjunctivitis. Curr Opin Allergy Clin Immunol. 2015;15(5):489-494.

4. Salehi A, Jabarzare S, Neurmohamadi M, Kheiri S, Rafieian-Kopaei M. A double-blind clinical trial on the efficacy of honey drop in vernal keratoconjunctivitis. Evid Based Complement Alternat Med. 2014;2014.

5. Mandal MD, Mandal S. Honey: its medicinal property and antibacterial activity. Asian Pac J Trop Biomed. 2011;1(2):154-160.

6. Abd Ghafar N, Ker-Woon C, Hui CK, Mohd Yusof YA, Wan Ngah WZ. Acacia honey accelerates in vitro corneal ulcer wound healing model. BMC Complement Altern Med. 2016;16:259.

7. Olaitan PB, Adeleke OE, Ola IO. Honey: a reservoir for microorganisms and an inhibitory agent for microbes. Afr Health Sci. 2007;7(3):159-165.

8. Majtanova N, Vodrazkova E, Kurilova V, et al. Complementary treatment of contact lens-induced corneal ulcer using honey: a case report. Cont Lens Anterior Eye. 2015;38(1):61-63.

9. Al-Waili N, Salom K, Al-Ghamdi A, Ansari MJ. Antibiotic, pesticide, and microbial contaminants of honey: human health hazards. Scientific World Journal. 2012;2012.

10. Said DG, Otri M, Miri A, Kailasanathan A, Khatib T, Dua HS. The challenge of fungal keratitis. Br J Ophthalmol. 2011;95(12):1623-1624. 